\title{
De la revolución interrumpida a su puesta en marcha. Compañero y una relectura revolucionaria del peronismo a comienzos de los 60
}

\author{
From the revolution interrupted to its start-up. Compañero and a revolutionary rereading of the Peronism in the \\ early 1960s.
}

\author{
Andrés N. Funes \\ CONICET - Instituto de Altos Estudios Sociales - \\ Universidad Nacional de San Martin, Argentina \\ funes.andres.n@gmail.com
}

\section{Resumen:}

El artículo examina la relectura del fenómeno peronista que se llevó acabo en Compañero, semanario ligado a los sectores combativos del peronismo a comienzos de los años sesenta. Se realiza un análisis hermenéutico del contenido de la publicación a partir de las herramientas metodológicas y teóricas elaboradas por la sociología de las identidades. El retrato que elabora Compañero sobre el peronismo le permitió, de forma simultánea, ligarse a la tradición peronista y también polemizar con los sectores que, pretendiendo ubicarse dentro del movimiento liderado por Perón, trataban de cuestionar el rol preponderante que aquel tenía. En este sentido, la recuperación de una "esencia revolucionaria" en el peronismo en la que embarcó el semanario le permitía no sólo restituir la autoridad lesionada de Perón sino más aún revalidarse como un actor legítimo dentro del movimiento.

Palabras clave: Peronismo, Años sesenta, Compañero, Revolución, Burocracia.

\section{Abstract:}

The article examines the reinterpretation of the Peronist phenomenon that Compañero, a weekly linked to the combative sectors of Peronism in the early 1960s, made. An hermeneutic analysis of the content of the publication is made from the methodological and theoretical tools elaborated by the sociology of identities. The portrait that Compañero elaborates about Peronism allowed it, simultaneously, to link to the Peronist tradition and also to polemicize with the sectors that, trying to locate themselves within the movement led by Perón, tried to question the preponderant role that he had. In this sense, the recovery of a "revolutionary essence" in Peronism that the Compañero developed allowed it not only to restore Perón's injured authority but even more to revalidate itself as a legitimate actor within the movement.

KEYWORDS: Peronism, Sixties, Compañero, Revolution, Bureaucracy.

\section{INTRODUCCIÓN}

El 5 de agosto de 1964, en un plenario desarrollado en el Sindicato del Calzado de la ciudad de Buenos Aires se conformó el Movimiento Revolucionario Peronista (MRP), el que podría considerarse como el más serio intento llevado a cabo por los militantes peronistas en la primera mitad de los años sesenta por aprovechar el denominado "giro a la izquierda" de Perón a comienzos de la misma década. ${ }^{1}$ El dirigente “jabonero" Gustavo Rearte y el delegado personal "insurreccional” de Perón, Héctor Villalón, fueron los artífices máximos del recién formado grupo. La constitución del MRP estuvo vinculada a las tensiones manifiestas entre Juan Domingo Perón y Augusto Timoteo Vandor. Villalón fue el encargado de reunir y agrupar a las distintas corrientes gremiales antivandoristas y grupos de la Juventud Peronista. ${ }^{2} \mathrm{Al}$ decir de Juan Bozza, el Movimiento se constituyó como una línea dura que se oponía a las cúpulas políticas y sindicales del peronismo seducidas por la política de integración y de compromiso del gobierno radical de Illia. Aún con una existencia breve, continua el autor, esbozó una "crítica anticapitalista sobre la estructura de clases 
de la Argentina, su régimen político, el gobierno, el sistema de partidos y sobre el rol de varios dirigentes del Movimiento Peronista (2001, p. 144).

En el plenario de agosto fue elegido como portavoz del MRP el semanario Compañero, dirigido por el médico y periodista Mario Valotta. Sus páginas mostrarían las ideas, deseos y proyectos del grupo recién formado. Compañero se editó a comienzos de los años sesenta, entre junio de 1963 y abril de 1965. Además de la pluma del propio Valotta, de ácidos y rutilantes editoriales, en sus 79 números ${ }^{3}$ desfilaron también periodistas y escritores como Rogelio García Lupo, Rodolfo Ortega Peña, Eduardo L. Duhalde, Germán Rozenmacher, Pedro L. Barraza y Julio Notta. Con una tirada de aproximadamente 35 mil ejemplares, Compañero tenía en los sindicatos -específicamente, los de farmacia y textiles- y en puestos de diarios de la Capital Federal sus lugares de venta. Asimismo, tuvo gran circulación en la Provincia de Buenos Aires y en ciudades del interior del país, como Rosario y Córdoba. ${ }^{4}$

No obstante, bien pronto, y posiblemente a raíz de desavenencias internas y, también, a cambios tácticos desde Madrid, los caminos de Valotta y el MRP tomarían otras direcciones. El primero sufriría de primera mano los vaivenes políticos de Perón, quedando sin sustentación económica y dejando de editar Compañero en abril de 1965. En lo que hace al MRP, por otro lado, un año después de haberse formado, las desavenencias internas entre sus máximos responsables lo habían horadado y la dispersión ya reinaba. Los años siguientes serían testigos de su virtual disolución. Para los años finales de la década de los sesenta, el MRP no era más que un recuerdo lejano en los nóveles grupos políticos formados al calor del "Cordobazo" y reverberancias posteriores.

El objetivo de presente trabajo no es realizar una historia o narración de las peripecias del MRP. Tampoco es un mero examen sobre el contenido factual que Valotta vertía en las páginas de su semanario. La intención de este escrito es, en contrapartida, analizar la concepción de peronismo que circuló en Compañero, utilizando para ello las herramientas metodológicas y teóricas elaboradas por la sociología de las identidades políticas. Se trata, dicho de otro modo, de apelar a un análisis hermenéutico de aquellas tramas de sentido construidas y disputadas en una coyuntura histórica específica. A este respecto, debe marcarse que no existen en la actualidad trabajos que se embarquen en un análisis exhaustivo del MRP. En la mayoría de los estudios que lo han referido, se lo concibió como una suerte de germen de las organizaciones político-militares peronistas de los años setenta (James, 1976; Gillespie, 1982; Gil, 1989; Lanusse, 2005).Algo similar sucede con el único trabajo que examinó al semanario Compañero (Raimundo, 2001). Sin menospreciar las relevantes reflexiones que estas investigaciones han realizado sobre el movimiento peronista en los años que median entre el exilio y el retorno de Perón, apelar a la teoría de las identidades, como se hace en este artículo, puede ayudar a repensar muchas de las ideas y conclusiones que ese conjunto de estudios sobre el peronismo ha elaborado. Asimismo, puede devolver al discurrir del peronismo de estos años muchos de los matices y contornos minimizados cuando no pasados por alto en estas investigaciones académicas "clásicas". En este sentido, entonces, de lo que se trata aquí es de profundizar y/o repensar algunas intuiciones capitales que estos trabajos canónicos han elaborado.

A los fines organizativos, el trabajo estará estructurado en dos partes. La primera de ellas está organizada derredor de la pregunta por la identidad. Allí se examina el concepto de identidades políticas, su relación con la historia y su utilidad a la hora de analizar fenómenos históricos. Luego, la segunda parte busca poner en juego la categoría de identidad política en lo que es la lectura que Compañero hace del peronismo. Como se pretende mostrar, el semanario busca insertarse en él haciendo suya, por un lado, la tradición peronista y apelando, por el otro, a lo que puede denominarse una lectura en clave "revolucionaria" del peronismo. El motivo de la "revolución" es una de las múltiples puertas de entrada para reflexionar sobre las reinvenciones a la que fue sometida la tradición peronista luego de 1955. En este sentido, este trabajo no pretende agotar las variadas aristas que presentó el peronismo para Compañero ni mucho menos solapar o negar el carácter de significante en disputa que tuvo la "revolución" para las distintas expresiones peronistas del periodo. ${ }^{5}$ Lo 
que se procura en el artículo es repensar una de esas reapropiaciones "revolucionarias" que se hicieron del fenómeno peronista en los años sesenta: la del semanario Compañero.

\section{¿QUÉ SON LAS IDENTIDADES?}

Una primera respuesta podría ser concebir a la identidad como una representación, una imagen creada y desde la cual las significaciones individuales y colectivas adquieren determinación. En otras palabras, concebirla como una construcción, "una ficción organizativa" (Yannuzzi, 2002, p. 283), mediante la cual los individuos no sólo se figuran la realidad que los circunda, sino que también les permite el reconocimiento mutuo entre los miembros de un mismo grupo.

Para Eduardo Restrepo (2007), por otro lado, el concepto de identidad presenta una serie de características. Para empezar, son relacionales. Esto es, se producen a través de la diferencia y no independientemente de esta. En este sentido, entonces, las identidades sólo son posibles en tanto establecen actos de distinción entre un orden interioridad-pertenencia y uno de exterioridad-exclusión. Ambos polos, no obstante, deben pensarse como mutuamente constitutivos. Luego, son procesuales, lo que significa que están históricamente situadas; son construcciones históricas, condensando, decantando y recreando, por tanto, experiencias e imaginarios colectivos. Asimismo, están discursivamente constituidas; son producidas, disputadas y transformadas en formaciones discursivas concretas. Son entendidas también como un provisional e inestable punto de sutura entre las subjetivaciones y las posiciones de sujeto. Por último, en tanto construcciones polifónicas y multiacentuales, las identidades acarrean multíplices, contradictorios e inconmensurables sentidos.

La definición deslizada líneas más arriba adolece de cierta abstracción, la cual dificulta su operacionalización a los fines de utilizarla, por ejemplo, en análisis históricos o sociopolíticos. No obstante, el trabajo de Gerardo Aboy Carlés (2001) ofrece elementos interesantes para mermar esa abstracción. Aquí las identidades son concebidas desde un punto de vista relacional, entendiéndolas como un conjunto de prácticas que constituyen, a través de un proceso simultaneo de diferenciación externa y unificación internas, solidaridades estables, con capacidad para definir orientaciones gregarias de la acción (Aboy Carlés, 2001, p. 54). En este sentido, examinar el devenir de una identidad política involucra indagar los complejos procesos de incorporación de elementos que revelan su constitución, el establecimiento de los límites precarios frente alteridad y también el inacabado trabajo de reinvención de la propia heredad.

La definición arriba propuesta decanta en tres dimensiones analíticas imprescindibles para el estudio de fenómenos histórico-políticos. En primero lugar, la alteridad, entendiendo que no puede haber identidades por fuera de un sistema de diferencias. Luego, la representatividad, esto es, un proceso de cierre parcial y precario de toda identidad. Y, por último, la tradición, en donde se arguye que toda identidad se configura referenciándose en un pasado y proponiendo la constitución de un futuro deseado.

Sin por ello despreciar las restantes dimensiones, es la última de ellas la que compete específicamente al trabajo que aquí se presenta. En lo que Aboy Carlés denomina "perspectiva de la tradición”, el pasado aparece como abierto, siendo reconstituido en función de un presente y un porvenir anhelado. La historia, por ejemplo, es escrita para y desde el presente. En este aspecto, cuando un actor bucea por los anales del pasado lo hace casi exclusivamente para brindar a su grupo de pertenencia un conjunto de seguridades. Asimismo, la reescritura del pasado es una herramienta fundamental a la ahora de polemizar con y descalificar a los enemigos de turno.

Esa naturaleza abierta y a la vez contingente de toda reescritura del pasado, es lo que permite hablar de su carácter "inventado". Eric Hobsbawn (1983) argumentó que todas las "tradiciones" no solamente son recientes en cuanto a su origen, sino que también producto de una invención. De este modo, ese conjunto de prácticas regidas por reglas aceptadas -explícita o implícitamente- y de naturaleza ritual o simbólica, cuyo objetivo estaría en inculcar ciertos valores o normas por medio de la repetición, que lógicamente indica continuidad con el pasado, son invenciones. El pasado es, así, reconstruido permanentemente por el grupo, 
donde la tradición se convierte en el medio indispensable a través del cual se organiza la memoria de la colectividad.

En definitiva, puede sostenerse con toda seguridad que el vínculo entre identidades e historia es capital. Algo similar sucede con el que se da entre política e historia. En relación con ello, Antonio Gramsci [1948] (2003) ha señalado, refiriéndose al concepto de historia en Benedetto Croce, que si el político es historiador -esto es, hace y también interpreta el pasado- es también un actor que transforma a la historia en contemporánea o política. En definitiva, las reconstrucciones épicas realizadas sobre el pasado se constituyen en fuentes fecundas para el análisis de los distintos discursos sobre el pasado, "prescindiendo por completo de cotejar los mismos con un supuesto 'pasado empíricamente dado' al que se referían” (Aboy Carlés, 2001, p. 69). Parafraseando a Ernest Renan [1882] (2010), entonces, los olvidos y errores históricos deliberadamente forman parte de todo regreso al pasado.

\section{UNA LECTURA REVOLUCIONARIA DE PERONISMO}

\section{La revolución en marcha (1945-1955)}

El 12 de octubre de 1963 asumía como presidente de la Nación Arturo Illia. La elección presidencial del 7 de julio lo había dado como ganador con un magro 25,9\% de los votos, frente a los casi 20 puntos porcentuales de voto en blanco, dinamizado no sólo por el llamado a "votar en blanco" que había lanzado desde el exilio español Perón sino también en virtud del sector radical intransigente vinculado a Arturo Frondizi. Ambos se encontraban imposibilitados de participar en las elecciones. Corrían similar suerte los partidos neoperonistas, a los cuales se les prohibió presentar candidatos.

Asimismo, la asunción de Illia coincidía con un hecho de envergadura para el peronismo. Tan sólo unos días después, el 17 de octubre, la Capital Federal, tras nueve años, ${ }^{6}$ se convertía nuevamente en el escenario de la conmemoración del "Día de la Lealtad", festividad insignia del peronismo. El acto central, no obstante, no tendría lugar en Plaza de Mayo -aquel terreno mítico en donde cada año del gobierno peronista el líder y sus acólitos renovaban la alianza tejida en 1945- sino que se llevaría a cabo en Plaza Miserere en el barrio de Balvanera, escenario en las primeras décadas del siglo XX de manifestaciones sindicales, socialistas y anarquistas. El peronismo, debe marcarse, llegaba a esta fecha profundamente divido entre un sector ligado a Vandor, dirigente de la Unión Obrera Metalúrgica, y otro opositor a este en los planos políticos y gremiales, vinculado, a grandes trazos, al sindicalismo "duro". La división, lógicamente, era producto de las reyertas intestinas por las que estaba atravesando el peronismo. Empero, la divisoria de aguas que comenzaba a producirse entre los elementos políticos y sindicales del peronismo no impidió que cuatro antitéticos personajes tomaran la palabra en el acto de octubre de 1963: Miguel Gazzera, Andrés Framini, Rubén Sosa y Delia Parodi (Melón Pirro, 2011).

La constitución del Cuadrunvirato en agosto de 1963-una suerte de organismo interventor conformado por Andrés Framini, Ilda Pineda de Molina, Julio Antún y Rubén Sosa, que tenía la tarea de reorganizar el Partido Justicialista-y las tensiones que comenzaron a gestarse al interior del peronismo permiten referirse a lo que se ha denominado la "línea dura" del peronismo. Para James McGuire, los "duros" "pertenecían principalmente a sindicatos chicos con escaso poder de negociación frente a los empleadores o al estado" que, a pesar del "tradicional anticomunismo del peronismo", reclamaban un programa que expropie a la oligarquía e implante el control obrero de la producción, tal y como rezaba el Programa de Huerta Grande de 1962. Entre los nombres que pertenecieron a esta línea, el autor menciona los de Amado Olmos, Roberto García, Jorge Di Pasquale y Ricardo De Luca, agregando, además, el de Andrés Framini ([1993] 2004, pp. 173-174). Daniel James sostiene que la "línea dura" constituyó un estado de ánimo, una actitud, una "estructura de sentimiento" más que en una posición política o ideológica articulada, porque el conflicto 
de clases del periodo entró en tensión con la ideología peronista formal (1990, p. 183).7 La disyuntiva "duros" y "blandos" va a ser utilizada por el semanario Compañero para trazar un retrato sobre el fenómeno peronista que le permita, en un mismo movimiento, ligarse a la tradición peronista y polemizar con aquellos sectores que dentro del peronismo ponían en cuestión la figura de Perón: los vandoristas. Se trataba, en definitiva, del trazado de una "esencia revolucionaria" del peronismo, presuntamente olvidada y obturada por las estructuras burocráticas que tenían la conducción política del Movimiento en el país.

Quizás no haya mejor demostración de este intento por delinear una dimensión revolucionaria del peronismo que las dos notas “¿Qué es la revolución?”, escritas por Andrés Framini y aparecidas en los números 20 y 21 de Compañero. Allí, sentencia el secretario general de la Asociación Obrera Textil:

Hemos señalado muchas veces que el peronismo es un Movimiento Revolucionario, que trasciende las fronteras de los partidos políticos tradicionales. Ninguno de estos cuestiona la estructura fundamental del país. Sus diferencias son de grados; difieren en lo secundario, coinciden en lo que es la defensa del actual orden de cosas, de la estructura económica y social oligárquico-capitalista, de la dependencia de las grandes potencias imperialistas, del carácter jurídico-político del liberalismo (Compañero, No 20, 1963, p. 3).

Con el 17 de Octubre de 1945, nuestro inmediato antecedente revolucionario no aparece en nuestra realidad como un simple acontecimiento político, sino como la continuación, bajo nuevas formas, de la misma Revolución Nacional iniciada a principios del siglo pasado. La importancia del 17 de Octubre trasciende de esta manera los objetivos concretos que animaron a las masas para movilizarse. Cuando el Pueblo, con los trabajadores a la cabeza, impuso la libertad a su LIDER, estaba realizando una revolución e incorporando un HECHO NUEVO a la historia moderna del país (...) [Con su acción, las masas populares] cambiaron el curso del país, arrancaron el poder a la oligarquía y al imperialismo e impusieron un gobierno integrado por las fuerzas populares (Compañero, № 21, 1963, p.3).

Dos cuestiones se derivan del extracto precedente. Por un lado, el carácter revolucionario y movimientista ${ }^{8}$ del peronismo, como puede apreciarse de la primera cita, se corresponden para Framini. Frente al peronismo se encuentran los partidos políticos tradicionales, aquellos que confluían, en contraposición al peronismo, parece sostener el autor de la nota, en la defensa del orden económico, político y social que regía en la Argentina. El carácter revolucionario del peronismo, entonces, estaría en su capacidad para poner en cuestión el orden de lo dado; esto es, para cuestionar los modos en que un orden se estructura y divide (Rancière, [1996] 2007). ${ }^{9}$ Y, por el otro, la revolución que venía a traer el peronismo no parece tener, se sigue de la segunda cita, un carácter ex nibilo. La irrupción del peronismo en aquella calurosa jornada de octubre del año 45 no hizo más que recuperar, parece sostener Framini, la estela legada por la "Revolución de Mayo" de 1810. A este respecto, Mariano Ben Plotkin, analizando el derrotero del "17 de Octubre" durante el primer gobierno de Perón, señala que es en 1947 cuando se produce la transformación de aquella fecha en una celebración patriótica. Esto es, se transforma en una fiesta de Estado, enlazándose al " 25 de Mayo" de 1810. En ambas oportunidades, "el pueblo había salido a la calle a defender sus derechos. Con esta operación, el peronismo implícitamente también se estaba apropiando de ésta última celebración patriótica” (1995, p. 204). Retomando lo expuesto por Framini, las masas, incluso no sabiéndolo, estaban produciendo una revolución con su movilización y la posterior liberación de Perón. Esto hacía del "17 de Octubre” algo más que un simple hecho político anecdótico; estese constituía, en todo caso, en el "inmediato antecedente revolucionario", mediante el cual las "fuerzas populares" que formaron el gobierno peronista "cambiaron la historia".

Una cuestión interesante que se deriva de lo dicho: aquella filiación que hace Framini entre el "17 de Octubre” y la gesta revolucionaria de Mayo debe ser vista como una reactualización de un conflicto pasado a la luz del presente. Esto es lo que sugiere Aboy Carlés (2001, p. 69) respecto de la construcción de un actor social imaginario que atraviesa el tiempo y el espacio como aparece en Eliseo Verón y Silvia Sigal ([1986] 2014, p. 195), la que se produce en la medida en que conflictos actuales son presentados como la configuración de conflictos históricos; ${ }^{10}$ ella permite no sólo dotar de sentido a la acción presente sino también reforzar la identidad del colectivo enlazándose a una herencia común. Entonces, la lógica que entiende al peronismo 
como revolucionario y a su nacimiento es un eco estentóreo de "Mayo", está enlazada a las necesidades del conflictivo presente.

Ahora bien, una pregunta fundamental se sigue de esto, y para la cual Framini no parece ofrecer respuesta en sus notas: ¿qué es precisamente la "revolución peronista"? Dicho más concretamente, ¿en qué habría consistido la estela revolucionaria del peronismo? Las páginas de Compañero, no obstante, sí ofrecen una contestación más que satisfactoria a estas inquietudes. El último de los Cuadernos de Compañero estuvo encargado de trazar una línea de continuidad entre el nacimiento del peronismo y la constitución del Movimiento Revolucionario Peronista en agosto de 1964. En la sección "Las grandes conquistas del gobierno popular" de la tercera entrega de Cuadernos, se aseguraba:

[E]l nuevo gobierno comenzó una obra de profundo contenido revolucionario (...) Se desarrolló así una industria de consumo que llegó a cubrir, prácticamente, las necesidades nacionales, sentándose las bases de la industria pesada. Todas estas grandes reformas quebraron el monopolio agrícolo-ganadero [sic]; fueron el resultado del impulso permanente de las masas movilizadas como contrapeso de las posiciones de la burguesía industrial, vacilante y frenadora, que encontró su principal aliado en el ejército. Esta contradicción alcanzó su máximo desarrollo cuando la continuidad del proceso revolucionario exigía completar el avance sobre los sectores parasitarios mediante la puesta en marcha de la reforma agraria y la nacionalización integral de los sectores claves de la economía. Allí se evidenció la oposición de la burguesía industrial (...) Se produce así la detención del proceso revolucionario (Cuadernos de Compañero, No 3, 1964 p. 11).

Como puede percibirse de la cita precedente, la irrupción del peronismo habría consistido per se un hecho revolucionario precisamente por el tenor de las políticas económicas implementadas durante su gobierno, las cuales, resultado del impulso permanente de las masas movilizadas, se orientaron a la constitución de una industria de consumo, quebrando el "monopolio agrícola-ganadero". En este sentido, si el tenor revolucionario del peronismo se lee desde el presente y precisamente a raíz de las políticas públicas que llevó adelante al haber llegado al gobierno, adquiere sentido la advertencia de Slavoj Zizek: "estamos todo el tiempo 'reescribiendo la historia', dando retroactivamente a los elementos su peso simbólico incluyéndolos en nuevos tejidos -es esta elaboración la que decide retroactivamente lo que 'habrán sido”' ([1989] 2009, pp. 88-89).En otros términos, el carácter revolucionario parece haberse manifestado una vez que esas políticas sucedieron y no antes, adquiriendo tal calificativo a posteriori. Sin embargo, el proceso revolucionario encuentra sus trabas precisamente cuando debía profundizarse, se lee en el extracto citado. Fue el accionar de la burguesía industrial, en alianza con elementos de las Fuerzas Armadas, el que impidió, detuvo, comenzó a frenar desde adentro, la reforma agraria y la nacionalización, aquellos índices de la profundización es la "revolución peronista”. Lógicamente la detención final coincidía con el golpe de Estado de 1955.

Para el caso de Compañero, por lo visto hasta aquí, sucedería lo contrario de lo que marca Guillermina Georgieff respecto del peronismo que se autopercibía en la izquierda del espectro político. Según la autora, este sector buscaba configurar a la Argentina bajo nuevas formas, yendo más allá de las banderas levantadas por el peronismo "ortodoxo" como estandartes del periodo 1945-1955: la soberanía política, la independencia económica y la justicia social (2008, p. 166). En Compañero, empero, existe una clara recuperación del periodo “1945-1955”. Ella constituía una época de oro, un pasado glorificado que tendría claramente un punto de inicio -el "17 de Octubre" - y uno final -septiembre de 1955 y la "Revolución Libertadora"-. Incluso, este pasado glorificado tenía un lugar para las elecciones de 1946. En este sentido, no sólo se refiere a ellas -Compañero, No 56, 1964, p. 4- sino también se las conmemora in toto-Compañero, No 35, 1964, p. 3-, al cumplirse 18 años. En ambos números, la recuperación de la victoria electoral se presenta como una instancia de legitimización de lo acontecido el "17 de Octubre”. Lejos del silencio o la mención sin más, entonces, la elección del 46 ocupa un lugar importante en Compañero. En este sentido, se ligaría a lo marcado por Eva Perón en Historia del peronismo respecto a las fechas que debían celebrarse en el peronismo ([1951] 1987, p. 163).

En lo que respecta a Compañero, podría hablarse aquí de una recuperación de la original acepción que tuvo la revolución según Hannah Arendt ([1963] 2012, pp. 55-57). Esto es, una revolución no involucraba otra 
cosa que la idea del regreso a un estado de cosas anterior, de la restauración a un punto pretérito luego de la interrupción del flujo histórico. En relación con esto, Julián Melo ha señalado el doble movimiento de heredad e innovación que opera en el discurso de Perón en los años de gobierno. ${ }^{11}$ No habría allí, entonces, una demonización de todo pasado sino tan sólo de aquel que trastocó el normal transcurrir evolutivo. En virtud de ello, el hecho revolucionario que el acaecer peronista venía a significar no parecía ser otra cosa que el colocar el país por una presunta senda perdida (2009, p. 108). Este motivo parecía estar aún presente en los primeros tiempos del Perón de exilio. En Los vendepatria, por ejemplo, argumentaba el caudillo: "Hemos tomado la iniciativa e impuesto nuestra ley de acción hace diez años y sería un terrible error (...) desandar lo andado. Nuestra solución es la Revolución Social Justicialista” (Perón [1958] 1974, pp. 148 y 149). En Compañero, este punto de retorno no parecía significar más que la restitución en el poder del gobierno peronista, cuyo paso previo debía ser el regreso de Perón al país.

Recuperando lo dicho anteriormente, el semanario editado por Valotta encuentra que la "esencia revolucionaria" no sólo estaba dada por la forma de irrupción del peronismo -la movilización popular y rescate de Perón el "17 de Octubre"- sino también, y quizás en un tenor mayor, por el contenido que el peronismo en el gobierno dio a sus políticas -constitución de un mercado interno como pilar de una industrialización pesada, por ejemplo-. Ambas, forma y contenido, parecen haber sido puestas entre paréntesis con el acaecer del golpe del año 55. En este sentido, podría tomarse y extenderse al periodo 1963-1965 la observación que realiza Ehrlich (2012, p. 198) a James (1990, p. 164): la recuperación y relectura que hace Compañero de las políticas del gobierno peronista y de sus conquistas sociales constituyeron elementos para resignificar los conflictos del presente. Tómese, por ejemplo, la serie de notas "El privilegio de la salud" que, en sus números inaugural y final-Compañero, No 51, 1964, p. 4 y Compañero, No 64, 1964, p. 4-, se refieren a la obra de la Fundación Eva Perón durante los nueve años de gobierno peronista, trazando un paralelo con la situación por la que atravesaba la salud bajo el gobierno de los radicales del pueblo en 1964.

Sin embargo, esta reivindicación de la naturaleza revolucionaria del peronismo, la que se habría manifestado desde su nacimiento y tomado cuerpo durante la década de gobierno, no debería conducir a pensar que para Compañero todas las manifestaciones que se presentaban como peronistas - un verdadero vitró a comienzos de los años sesenta- tenían legítimas credenciales "revolucionarias”. En otras palabras, no es posible sostener que para el semanario "todo el peronismo es revolucionario" (Raimundo, 2001, p. 217); ${ }^{12}$ tan sólo lo era, para Compañero, el "inactual", "legítimo" y "verdadero" peronismo, para decirlo con Altamirano, ${ }^{13}$ que el propio semanario aducía representar.

Nada ejemplifica mejor esta aserción que "Historia de un proceso. Las dos líneas del peronismo. Revolución o conciliación”, larga nota sobre las líneas que se formaron en el peronismo desde su génesis. En el centro, flanqueado por dos columnas, ${ }^{14}$ se dice:

Desde que el Movimiento Peronista irrumpió en la escena política argentina, dos corrientes opuestas se han enfrentado permanentemente por la preeminencia ideológica y política en la dirección: la revolucionaria y la conciliadora. La primera surge de las masas y se proyecta hacia la conducción del proceso de Liberación por la clase trabajadora. En las etapas en que ha logrado prevalecer, ha permitido conquistar las grandes victorias populares y antiimperialistas que jalonan los grandes avances del Peronismo. La segunda, la línea conciliadora, tiene sus raíces en los elementos burocratizados que sirven de correa de transmisión a las ideas claudicantes de la burguesía que se ligó al imperialismo yanqui. Cuando este sector logró contener la expresión auténtica de las bases e imponer sus posiciones de conciliación con los enemigos del pueblo, se produjo la detención de la revolución o aún su retroceso (Compañero, № 62, 1964, p.4).

Se ve, entonces, como el peronismo, desde su propio nacimiento, habría parido dos tendencias antagónicas, las que lucharon por imponer su hegemonía dentro del movimiento. De un lado, los sectores revolucionarios, artífices de las "grandes victorias populares y antiimperialistas" que dan la nota en la historia del peronismo. Del otro, los sectores conciliadores, "enemigos del pueblo", caracterizados por su presunta esencia burocrática, por tomar el lugar de “correa de transmisión” de intereses ajenos al sentir popular y por 
frenar la potencialidad "revolucionaria” del peronismo. En 1955, se plasmaría la hegemonización del sector conciliatorio, traduciéndose en el triunfo de la "Revolución Libertadora" y ocasionando la "detención de la revolución”. Por lo tanto, aquí podría marcarse una tensión con la visión de "edad de oro" en el periodo 45-55 mencionada más arriba. Esto es, aquella época venturosa parece no haber estado exenta de conflictos y “manchas". Estos, en todo caso, acompañaron su discurrir, para terminar horadándola.

Asimismo, para el semanario, ambos polos antitéticos habrían manifestado su naturaleza precisamente en el hecho inaugural del peronismo: el "17 de Octubre". Las masas, "superando las vacilaciones y el temor de la burocracia incipiente" (Compañero, No 62, 1964, p. 4) y desbordando los "propios organismos sindicales" (Compañero, No 18, 1963, p. 3), habrían tomado la resolución de movilizarse "sin esperar el resultado de la reunión de la CGT” (Compañero, No 68, 1964, p. 4). ${ }^{15}$ En definitiva, el nacimiento de ambos sectores coincidiría, para el semanario, con una superación, un desborde, un desoír de los revolucionarios a los conciliadores. En tanto construcción de un mito de origen -esto es, "hablando del pasado, proporcionan categorías que permiten comprender el presente y planear el futuro” (Neiburg, 1995, p. 231)-, destacar aquella dimensión "subversiva" de las masas frente a sus dirigentes en octubre de 1945 tenía la función de presentar los conflictos presentes entre las dirigencias sindicales y sus bases bajo una nueva luz; recuperando mediante el relato aquella esencia disruptiva de las masas, se trataba de filiar las luchas presentes con aquellas que habían tenido estas en el alumbramiento del fenómeno peronista.

Respecto de quienes habían conformado desde el nacimiento del peronismo esa línea conciliatoria, para Compañero no existían dudas. En la misma "Historia de un proceso..." se dice sobre el año 55:

El cerco de burócratas y traidores ahoga y detiene la revolución, impidiendo la profundización de la labor transformadora del peronismo. La CGT neutralizada también por burócratas y tránsfugas, deja de ser el instrumento de movilización de las masas, para convertirse en su freno. Los repetidos llamados de Perón para la formación de las milicias obreras que Evita también había impulsado como armada de defensa de la revolución, para enfrentar al ejército, ya definido como brazo armado de las fuerzas de burguesía proimperialista, se encontraron con el sabotaje de la burocracia, que presionaba en favor de la conciliación con los enemigos del pueblo (Compañero, No 62, 1964, p.4).

La burocracia dirigente, la que había colonizado la CGT, habría tendido un cerco alrededor de Perón, impidiendo la "profundización de la labor transformadora del peronismo". Este cercamiento de la "Revolución Peronista" se tornaba palpable en la negativa de formar "milicias obreras", negativa que presuntamente partía de los sectores burocráticos en alianza con el ejército. Estos sectores, en vez de lanzarse a la defensa del gobierno peronista, apostaron a la "conciliación con los enemigos del pueblo". El motivo del "cerco" no es una novedad del discurso de Compañero. Ya en una carta a Perón, Cooke advertía que junto al líder y a la masa revolucionaria, se daba también una "capa burocrática -sindical, política y administrativas- que actúa de aislante y no de mecanismo de transmisión, de freno y no de ejecutora de la política revolucionaria” (2014, p. 477). Aún más, César Tcach, en su trabajo sobre la participación de representantes tradicionales como Acción Católica o el Partido Conservador en la "invención" del peronismo cordobés, muestra la presencia de una suerte de "teoría del cerco" en el laborismo cordobés de mitad de los cuarenta ([2003] 2014, p. 33). ${ }^{16}$

Retomando lo expresado en Compañero, la burocracia habría tenido también un papel destacado en otro hecho de envergadura, el cual, dejando una marca indeleble en el peronismo, habría constituido la piedra de toque del "ahogo" y "detenimiento" revolucionario: el "Renunciamiento de Evita" del 22 de agosto de 1951, como lo denomina la hagiografía peronista. Para el semanario, la declinación de Eva Perón a conformar la fórmula presidencial está ligada íntimamente al accionar de la burocracia, "instrumento de la traición de la burguesía y de las fuerzas militares". La negativa de la segunda esposa de Perón a la vicepresidencia marcó el comienzo, se señala, del "cerco que tiende a impedir el contacto de las masas con el Líder" (Compañero, No 62,1964, p.4). Por tanto, mucha parecía ser la responsabilidad que cabía sobre los hombros de los elementos burocráticos. 
No obstante, el "Renunciamiento" tenía, para el semanario, una función también didáctica. Recordando el episodio, Felipe Ludueña, miembro del Secretariado Ejecutivo del MRP por Santa Cruz, observa:

\begin{abstract}
Pero los puestos no es lo que determina la conducta de los verdaderos revolucionarios, desde el llano junto al Pueblo, a pesar de su quebrantada salud, el trabajo Revolucionario continuó. El 22 de agosto de 1951 la compañera EVITA, humilde soldado salida de las filas del pueblo no aceptaba el honor del alto puesto, este renunciamiento (...) nos debe hacer meditar profundamente, nos debe dar la pista para descubrir en la conducta de los que circunstancialmente conducen el movimiento, sin vocación revolucionaria, sin abnegación, sin humildad, la reiteración de aquellos episodios, tratando nuevamente hoy de cercar y anular a los que consustanciados con el espíritu de lucha y esclarecida conciencia histórica de las masas se ponen a su servicio llevándolas a la Revolución y a la victoria (Compañero, № 60, 1964, p. 8).
\end{abstract}

La renuncia de Eva Perón, entonces, debía ser concebida como un mecanismo que conduzca a la reflexión acerca de la conducta de los que "circunstancialmente" eran los dirigentes peronistas en el país. Ella prefirió renunciar al puesto político y continuar su trabajo "desde el llano junto al Pueblo". Lo contrario ocurriría con esos dirigentes políticos y sindicales que "sin vocación revolucionaria, sin abnegación, sin humildad" -características todas asociadas a la figura de Eva- continúan "cercando" y "anulando" la presuntamente endémica esencia revolucionaria de las masas peronistas. Nuevamente, la responsabilidad era sólo de los dirigentes burocráticos.

La imagen que ofrece Compañero respecto del "Renunciamiento" puede poner en tensión la lisa y llana asociación de Eva Perón con la ética de la convicción y de Perón con la ética de la responsabilidad (Sarlo, 1999, pp. 348-349 y 2003; p. 27; Slipak, 2015, p. 89). Sopesando las dificultades que podría traerle a Perón que aceptase su candidatura a vicepresidente -esto es, valorando las consecuencias de sus actos-, Eva habría decidido declinar su aceptación y “volver al pueblo". La declinación, no obstante, obedecería también a una convicción: obligación moral y seguimiento apasionado de principios. En este sentido, no hay que olvidar que ambos son tipos ideales y, como recuerda su artífice, "no son términos absolutamente opuestos, sino elementos complementarios que han de concurrir para formar al hombre auténtico, al hombre que puede tener «vocación política»" (Weber, [1967] 2007, p. 177. Cursivas en el original).

No es para nada casual este real o aparente rol protagónico que el semanario daba a la burocracia. Al decir de James (1990, p. 217), el ciclo que se abre entre fines de 1962 con la casi total recuperación de la CGT por los peronistas y las postrimerías del golpe de Estado de Juan Carlos Onganía en 1966, puede ser denominado "La era de Vandor". Aquel expresaba la "tensión latente entre los dirigentes sindicales, que querían un acceso autónomo al estado, y Perón, que quería mantener el control de sus seguidores” (McGuire, [1993] 2004, p. 181). Representaba, como sostiene el autor de Resistencia e integración, la tentativa sindical de consolidar e institucionalizar el poder acumulado en tanto representantes de los trabajadores organizados y expresión legal del peronismo (James, 1990, p. 263). Con Vandor, y como nunca antes, la posibilidad de organizar un partido político peronista sin Perón cobraba reales dimensiones. Otra forma de decir, amparándose en el poder del gremialista oriundo de Entre Ríos, la puesta en cuestión del lugar de Perón parecía ser una realidad.

La tentativa de Compañero de filiar a los sectores sindicales que representaba Vandor con el "Renunciamiento de Evita" y con el golpe de Estado de 1955 se dirigía no sólo a negarles su pertenencia al peronismo y, en un mismo movimiento, restituir a Perón el rol al parecer negado. Esta filiación estaba también orientada a presentar a los que hablaban a través del semanario como los auténticos representantes del movimiento; aquellos que, recuperando la estela revolucionaria del "17 de Octubre” y de las políticas del gobierno peronista, se mantenían incólumes detrás de su conductor y máximo artífice, en momentos en que su lugar estaba tratando de ser erosionado.

A este respecto, dicha vinculación se relaciona con dos argumentos que Hannah Arendt despliega en relación a la tradición romana. Por un lado, la religión fue entendida como la acción de "volver a ser atado, obligado por el enorme y casi sobrehumano, y por consiguiente siempre legendario, esfuerzo de poner los cimientos, de colocar la piedra fundacional, de fundar para la eternidad" ([1954] 2016, p. 192). Y, por el otro, la autoridad, en una íntima relación con la antedicha, era la que permitía aumentar el poder de la 
fundación -aquel comienzo sagrado de la historia- como fuerza vinculante que adquiere su peso específico en el pasado. Así, en tanto el pasado y la tradición no fuesen interrumpidos, la autoridad se mostraba intacta. En Compañero, entonces, el religarse a la tradición peronista, edificando específicamente la dimensión revolucionaria que presuntamente tuvo su acaecer, permitía al semanario no sólo restituir la autoridad lesionada de Perón sino más aún revalidarse como un actor legítimo dentro del movimiento.

En esta revalidación, asimismo, se traslucen dos motivos caros al peronismo verdadero, tal y como señala Altamirano ([2001] 2013, p. 131). En primer lugar, la tarea del rescate, sea este de Perón, del pueblo o de la Patria. Debe marcarse que el motivo del rescate a Perón presuntamente ocurrido el "17 de Octubre" que se encontraba ya mencionado en los discursos de Eva Perón del "Día de la Lealtad” de 1949 y 1950 , y brevemente en algunos pasajes de La razón de mi vida ([1952] 2006, p. 86)- se repite con insistencia en las páginas de Compañero: “¿Es que ya se olvidó que en 1945 el Pueblo triunfó sobre la oligarquía y el imperialismo, rescatando a su líder?" (Compañero, No 12, 1963, p. 6); "El pueblo lo rescató de las garras de la oligarquía a nuestro querido Perón" (Compañero, No 31, 1964, p. 6); "La clara conciencia de que era necesario ir a la lucha para rescatar a Perón y derrotar a la oligarquía había lazando a la clase trabajadora a la calle” (Compañero, No 68, 1964, p. 4). Es posible que el tópico del rescate haya tomado cuerpo estando Perón en el exilio. A partir de la restitución que de este hace el semanario, se estaba insistiendo en la necesidad de que se produjese un nuevo rescate de Perón casi 20 años después. Y, en segundo lugar, el motivo del expresar o develar una esencia circunstancialmente eclipsada -su naturaleza revolucionaria, como se vio más arriba- tanto por la proscripción como también por las inconsecuencias del peronismo reinante. Esto permite coincidir con Altamirano: el presente no parece ser nunca el tiempo del peronismo verdadero ([2001] 2013, p. 132).

\section{La revolución pausada (1956-1964)}

El 16 de septiembre de 1955 el general Eduardo Lonardi comandó un levantamiento militar cuyo objetivo fue el derrocamiento del gobierno peronista. Tan sólo unos días después, el 23 de septiembre, un Lonardi triunfante asumía como presidente provisional. Sin lugar a dudas, la cuestión principal con la que tuvo que lidiar el campo no-peronista, sentimiento que motorizó el golpe, fue la de qué hacer con el peronismo y los peronistas una vez destituido su líder. La respuesta fue proceder hacia un proceso de “desperonización”, el que se convirtió, como señala agudamente María Estela Spinelli (2005, p. 54), en un signo distintivo y nueva fuente de conflictos y frustraciones para el gobierno surgido de la "Libertadora". La desperonización involucró toda una serie de medidas que iban desde la remoción de los nombres de Perón y de su segunda esposa de toda calle, plaza o institución que hubiese sido bautizada de ese modo, la prohibición de libros con "contenido peronista" o de la famosa marcha "Los muchachos peronistas", hasta la intervención de la Confederación General del Trabajo (CGT), la detención de exlíderes políticos y sindicales peronistas y la purga de militares presuntamente simpatizantes del régimen depuesto.

Ahora bien, Compañero, a la hora de hacer un racconto de los hechos sucedidos entre este 1955 y su presente, la primera mitad de los años sesenta, es terminante. Basten a la sazón los siguientes ejemplos:

A través de estos años de dura experiencia, muchos mártires fueron escribiendo con sangre peronista la historia de un país en guerra. Una guerra sorda y disimulada entre un ejército de represión que actúa como fuerza de ocupación y la clase trabajadora (Compañero, No 18, 1963, p.3).

Estos duros ocho años, de vejaciones contra dirigentes obreros y populares, de fusilamientos y crímenes contra el pueblo, al que se pretendió dominar por medio del soborno, la violencia y el hambre, han probado el alto grado de politización alcanzado por las clases oprimidas durante 10 años de gobierno peronista. Ni el fraude ni las proscripciones, ni las torturas ni las continuas desapariciones de representantes obreros han servido para ablandar un ápice el espíritu combativo del pueblo y del Movimiento Peronista, que lo expresa (Compañero, No 35, 1964, p. 3).

[Tras el derrocamiento de Perón] [s]e asesina a los patriotas -Valle, Cogorno, Vallese, son claros ejemplos-, se proscribe al pueblo y miles de compañeros presos y torturados pagan la culpa de pensar como verdaderos argentinos. La miseria, el hambre y la desesperación invaden los hogares argentinos; la carne es un artículo de lujo que comen los extranjeros y los ricos, 
el pan y otros artículos de primera necesidad se encarecen día a día; las villas miseria, la mortalidad infantil, la desnutrición, la desocupación proliferan (Compañero, No 57, 1964, p. 6).

Estos tres extractos son sumamente sugestivos a la hora esbozar la imagen de lo que para el semanario significó el acaecer de la "Libertadora". Ella simbolizaba, en este sentido, un total y completo quiebre respecto de aquella época de oro del decenio peronista; una suerte de Caída del Paraíso, dicho en términos afines al pensamiento cristiano. Pululan en los extractos mencionados más arriba palabras como "guerra", "vejaciones", "torturas", "fusilamientos", "hambre”, “miseria”, "desesperación”, por sólo citar algunas. Los años que inaugura el golpe de 1955 son aquellos que hablarían de la "historia de un país en guerra" entre un ejército represivo y la clase obrera. Años, en fin, de una "dura experiencia".

Un lector atento habrá notado en el segundo extracto citado dos referencias sumamente interesantes. Por un lado, el "alto grado de politización alcanzado por las clases oprimidas durante los 10 años de gobierno peronista". Y, por el otro, que las medidas represivas tomadas desde las postrimerías del golpe del 55 no habrían "servido para ablandar un ápice el espíritu combativo del pueblo y del Movimiento Peronista". Si se acepta que la muerte es el epítome del golpe de 1955, para el peronismo, en general, y para Compañero, en particular, el señalar la persistencia de ese espíritu combativo adquiere aún más sentido. Arendt ha marcado que la experiencia de la muerte adquiere un nuevo sentido cuando se la vive colectivamente; nada puede intensificar tanto la vitalidad humana, aseguraba la pensadora alemana, como la proximidad de la muerte ([1972] 2015, p. 170). He aquí, entonces, una curiosa inflexión respecto de aquella visión lúgubre y melancólica de "la Caída". Ella permitiría expresar un carácter oculto, soterrado: la politización y el espíritu combativo del peronismo. ${ }^{18}$

Ambas características serían las que habrían primado en los años que siguen al golpe y que se expresaron en algunos hechos puntuales. Estos son: 1) el levantamiento militar de Juan José Valle en junio de 1956; 2) la huelga y toma del Frigorífico Nacional Lisandro de la Torre en enero de 1959; 3) la frustrada victoria electoral peronista de marzo de 1962; y 4) la Asamblea del 5 de agosto de 1964 que constituye el MRP. Esta incorporación de fechas y eventos sucedidos en los primeros años que siguen a la "Libertadora" tendrán como objetivos no sólo remarcar esa politización y espíritu combativo del pueblo sino también develar el supuesto contubernio entre los dirigentes sindicales y el sistema político-económico. Esto reforzaría la necesidad de dar al peronismo una otra dirigencia que delinee, asimismo, una nueva forma de lucha cuyo objetivo fuese el regreso de Perón al país.

Sobre las mencionadas fechas, se dice:

El 9 de junio [de 1956] se realiza el primer intento armado del pueblo para conquistar el poder. El ejército de ocupación logró frustrar el movimiento quedando demostrado que el método elegido era erróneo. Pero la jornada que constituye una bandera de lucha en manos del pueblo, puso de manifiesto la profundidad del odio que sienten las clases privilegiadas por quienes asumen la causa popular y enriquecen la experiencia de la lucha por la liberación (Compañero, No 50, 1964, p. 4). La ocupación del frigorífico Lisandro de la Torre[en 1959] marca, por sí sola, una de las jornadas más combativas que vivió nuestro pueblo trabajador en los últimos ocho años y sí esa combatividad no sirvió todavía para terminar con el derrocamiento definitivo del régimen de opresión, no ha sido, precisamente, por la falta de garra de los trabajadores, sino, muy por el contrario, por la actitud de ciertos dirigentes que mediante la camándula y el mangoneo de votos se han enquistado en las direcciones gremiales transformándolas en una cerrada burocracia contrarrevolucionaria que transa, concilia, y se agacha frente a los enemigos del pueblo (Compañero, No 30, 1964, p. 5).

El 18 de Marzo de 1962 marca el fin de la retirada popular y el comienzo de la ofensiva de las fuerzas nacionales hacia la reconquista del PODER. El triunfo de los candidatos del PUEBLO, obtenido en las peores condiciones de desigualdad, revela la fortaleza del campo nacional cuando posee una dirección táctica revolucionaria y aplica a la realidad los métodos de lucha correctos (Compañero, No 16, 1963, p. 6).

Es perceptible el hilo conductor que se mencionaba anteriormente. Por un lado, el levantamiento del general Valle en 1956 es presentado simultáneamente como primer mojón del intento del pueblo por recuperar el poder a través de las armas, censurándose duramente el método empleado: la sublevación militar. Luego, la "toma” del Frigorífico Nacional Lisandro de la Torre es presentada como una de las jornadas más 
“combativas" que vivió el pueblo. Si esta no pudo concretar el "derrocamiento definitivo del régimen de opresión" se debió pura y exclusivamente a la actitud de los dirigentes burocráticos, los cuales presuntamente coartaron las posibilidades abiertas a raíz de aquel conflicto. Y, por otro lado, el triunfo peronista en las elecciones de 1962 es presentado como la "contraofensiva" de las "fuerzas nacionales", posibles precisamente por estar conducidos por una "dirección táctica revolucionaria" que aplica los "métodos de lucha correctos". En otras palabras, estos "estertores revolucionarios" mostrarían el equívoco de confiar en una sublevación militar y fiarse de los dirigentes burocráticos, lo que conduce a la necesidad de renovar las conducciones tácticas -la estratégica era la de Perón en el exilio, claro está-, a los fines de explotar las posibilidades que abrían los episodios de combatividad.

Asimismo, la reconstrucción que hace el semanario de los tres hechos mencionados hace emerger una tensión entre el rechazo del golpismo, la utilización de una gramática bélica y una reivindicación del proceso eleccionario. En primer lugar, el rechazo al golpismo con toda seguridad se debió no sólo al rol pretoriano de las Fuerzas Armadas después de 1955 sino también al involucramiento creciente de estas en las tareas represivas en el marco del Plan de Conmoción Interna del Estado (o CONINTES). ${ }^{19} \mathrm{~A}$ este respecto, es bastante discutible, en lo que se refiere a Compañero, aquello que menciona Marcelo Raimundo (1998, p. 229) acerca de la pervivencia de cierta impronta golpista en el imaginario posperonista (1955-1966). Recurrir a un golpe de Estado cívico-militar que derrocase al gobierno radical de Illia no se consideraba como una opción idónea, se marca en el semanario. De forma similar, Cooke manifestaba, en su correspondencia con Perón en septiembre de 1962, su oposición al mecanismo del golpe (2014, pp. 536 y 559). El propio Perón, en Los vendepatria, descreía de la "fuerza y el golpe de estado militar, como se ha ensayado sin éxito hasta ahora [se refiere a la insurrección de Valle], (...) [ya que] es exponer al Pueblo a inútiles sacrificios" ([1958] 1974, p. 148).

En segundo lugar, en lo tocante al uso de un lenguaje bélico, la progresiva identificación de los gobiernos militares y civiles del periodo pos 1955 con los intereses imperialistas haría a los círculos peronistas acuñar una serie de fórmulas o imágenes "para describir la nueva situación (...) Entre tales imágenes, se destaca la del 'país ocupado', ya en la versión de la 'invasión' o en la de una Argentina ‘bajo fuerzas de ocupación’” (Ehrlich, 2012, p. 170). Si bien es cierto que la idea del "invasor" aparece a finales de 1955 en una carta que Alejandro Leloir envía al General Pedro Eugenio Aramburu frente al decreto de disolución del Partido Peronista, la idea de que las Fuerzas Armadas que se hicieron con el poder en septiembre constituyen un "ejército de ocupación" fue esbozada por Perón en Los vendepatria ([1958] 1974, pp. 141-142). Asimismo, este motivo vuelve a aparecer en el mensaje que dirige Perón a las huestes concentradas en celebración del " 17 de Octubre" de 1963 en Plaza Miserere (Baschetti, 2012, p. 279).

$\mathrm{Y}$, en tercer lugar, la reivindicación de las elecciones obedecía a una suerte de reafirmación del poderío de las huestes peronistas si las barreras de la proscripción eran levantadas. De similar forma al recuerdo que Compañero dispensaba a las elecciones de 1946, las de marzo de 1962 simbolizaban una reafirmación de la naturaleza revolucionaria que anidaría en las masas peronistas cuando tiene una conducción táctica y una estrategia de lucha correctas. Empero, no era esta, por ejemplo, una opinión compartida por Cooke. Para el otrora apoderado del Movimiento Nacional Justicialista, "aunque se afirme lo contrario, la lucha electoral [de marzo de 1962] debilitó la estructura de lucha revolucionaria en el Movimiento” (2014, p. 530). ${ }^{20}$

En este sentido, a los ojos de Compañero, entonces, la frustrada experiencia de las elecciones de marzo del 62 representaba una cesura especial respecto a los anteriores hechos mencionados. Tómese, por ejemplo, el número 38 que rememora el " 18 de Marzo" a dos años de producido. Allí se dice que, tras las elecciones, "toda la fachada democrática del régimen se desmorona” y que la elección de Andrés Framini como gobernador de Provincia de Buenos Aires "[i]ndica que la conciencia popular está a punto para realizar el movimiento revolucionario que nuestro país requiere" (Compañero, $\mathrm{N}^{\circ} 38,1964$, p.5). En otra nota del mismo número se habla de una "verdadera revolución en las urnas", que "obligó a la oligarquía y a sus sirvientes a quitarse la máscara y a evidenciar ante toda la Nación que no está dispuesta a entregar pacíficamente el poder 
que arrebató por la fuerza" (Compañero, No 38, 1964, p.5). Finalmente, un comentario de la Juventud Universitaria Peronista (JUP) vuelve sobre el motivo de desvelamiento de los verdaderos fundamentos del orden político, concluyendo que los episodios de marzo del62 demostrarían que las "elecciones sólo son una de las formas de lucha que debemos adoptar dentro de un objetivo inalterable: el regreso de General Perón a la Patria y el poder" (Compañero, 38, p.5). En definitiva, la reivindicación del "18 de Marzo" en Compañero puede poner parcialmente en duda la entronización sin más de un "pensamiento virulentamente antielectoralista" en el peronismo que se presentaba como revolucionario en los años sesenta (Bozza, 2001, p. 158). Parcialmente en tanto la experiencia truncada de marzo mostró que el acceso al poder no se haría mediante el voto sino que el camino era la revolución.

En esta reconstrucción que se hace del "18 de Marzo" no puede dejar de remarcarse el curioso silenciamiento respecto al importante papel que tuvieron durante la campaña tanto el "Consejo Coordinador y Supervisor del Peronismo” (CCS) ${ }^{21}$ como también el sindicalismo y la Unión Obrera Metalúrgica liderada por Vandor (Tcach, [2003] 2007, p. 37). El desconocimiento del rol jugado allí por el aparato político y sindical peronista y, en cambio, el hecho de reparar lisa y llanamente en la actuación de la "conciencia popular" en las urnas, calificándola de "revolución en las urnas", tenía el objetivo de deslegitimar el lugar de aquella dirigencia dentro del peronismo. Aún más: esta no sólo no habría tenido un rol importante en el discurrir electoral sino más aún "no supo canalizar la expresión valiente y combativa que a través de las urnas significaba el repudio y la liquidación de las fuerzas oligárquicas y el imperialismo” (Compañero, No 30, 1964, p. 6). En definitiva, estas cumplieron nuevamente, según el semanario, un papel obstruccionista.

Un nuevo extracto de "Historia de un proceso..." puede servir para ilustrar esto. En una subsección titulada sugestivamente "Los mariscales de la derrota" se dice:

Después de la infamia frondicista del 'Conintes', la decisión popular de castigar la traición en las elecciones del18 de marzo marcó el comienzo de una nueva etapa. De allí en adelante el proceso de definición revolucionaria que expresara e impulsara “DEMORACIA" primero, “18 DE MARZO” después y “COMPANEERO” ahora, se hizo incontenible, culminando en la histórica jornada del 5 de agosto [de 1964] (Compañero, No 68, 1964, p. 4).

Si al "18 de Marzo" se lo presenta como un quiebre que inaugura el "comienzo de una nueva etapa”, la asamblea que da nacimiento al Movimiento Revolucionario Peronista en agosto de 1964 va a ser presentada como la culminación de los sucesos "revolucionarios" acaecidos entre la sublevación de Valle en el año 56 y el tiempo presente. Resulta asimismo evidente el lugar que al respecto se otorga el propio Compañero; este no hizo más que recuperar, promover y ahondar un trabajo ideológico legado por otros dispositivos periodísticos como el diario Democracia y el semanario 18 de Marzo, ambos dirigidos por el mismo Valotta.

Más adelante, en el mismo artículo, se concluye:

[L]os "mariscales de la derrota" son los portadores naturales de una nueva maniobra reaccionaria tendiente a contener el nuevo ascenso de las masas. El Peronismo Revolucionario, leal a Perón y consciente de su fuerza, aguarda sereno el fin de la farsa que significará al mismo tiempo la fosa de los traidores, a los que Perón ha obligado a asumir la responsabilidad total por el fracaso poniendo plazo fijo a sus negociaciones espurias con el régimen. De allí en adelante, la palabra la volverán a tener las masas que sabrán expresarse con el lenguaje contundente del plomo (Compañero, № 68, 1964, p. 4).

Sin embargo, aún a pesar de que ese incontenible "proceso de definición revolucionaria" haya tomado cuerpo con la constitución del MRP, la burocracia política y sindical -los "mariscales de la derrota” - tenían aún el potencial para obturar -tal y como hicieron en el pasado- el "nuevo ascenso de las masas". Esta vez el propio Perón indicó la necesidad de que los sectores burocráticos asuman la "responsabilidad total por el fracaso". Esto permitía al peronismo "leal" a Perón, el "Peronismo Revolucionario", mantener la calma y esperar "el fin de la farsa". Al sortear el "cerco" tendido por los elementos burocráticos, Perón habría deslegitimado el lugar de estos, inclinándose, lógicamente, por los sectores "leales". A partir de esta acción, "la palabra la volverán a tener las masas"; otra vez, como la historia del peronismo parecía haber mostrado, 
aquellas desbordarían como un río caudaloso a sus dirigencias e impondrían el "lenguaje contundente del plomo".

\section{Conclusiones}

El trabajo realizado analizó la relectura que Compañero elaboró sobre el fenómeno peronista a comienzos de los años sesenta. En otras palabras, se examinó, apelando a una estrategia de análisis de tipo hermenéutico, el modo en que el semanario releyó la tradición peronista. Esto permitió visualizar, asimismo, algunas aristas relevantes que presentan estas construcciones acerca del pasado, tendiente no sólo a explicar lo que ha acontecido sino también a proyectar el futuro y redefinir así el sentido de la acción presente. Como se buscó mostrar, Compañero apeló a una lectura en clave revolucionaria de la tradición peronista. En tanto significante en disputa durante el periodo, esta redefinición y reapropiación del peronismo como "hecho revolucionario" le permitió a este sector del movimiento liderado por Perón, que se expresaba a través del semanario, solidificar el espacio propio y marcar aquellos elementos que atentaban contra la unidad de ese campo.

En una primera parte se analizó qué se entiende conceptualmente por identidad política. Se precisó, además, el rol que la historia, la "perspectiva de la tradición” en términos de Aboy Carlés, tiene en los procesos identitarios. Se llegó así a la conclusión de que los "usos de la historia" son columnas ineludibles de los que se vale la constitución de toda identidad sociopolítica. Esto significa poner en tensión aquellas hipótesis que sostienen la existencia de una "verdadera historia” a la que la política no haría más que alterar o ensombrecer. En este sentido, todo hurgamiento en el pasado lleva deliberadamente consigo una herencia de olvidos y errores.

Con todo ello en mente, en la segunda sección se muestra la imagen que conformó Compañero del peronismo. Este retrato le permitió en forma simultánea, como ya se deslizó, ligarse a la tradición peronista y polemizar contra los sectores que, pretendiendo ubicarse dentro del movimiento, trataban de cuestionar el rol preponderante del propio Perón. De esto se trataba esencialmente la recuperación de una "esencia revolucionaria” en el peronismo en la que embarcó el semanario. Así, subrayar aquella supuesta dimensión revolucionaria permitía al semanario no sólo restituir la autoridad lesionada de Perón, sino más aún revalidarse como un actor legítimo dentro del movimiento.

Ese restablecimiento de la faz revolucionaria involucraba: I) reconocerle una capacidad para conmover el orden de lo dado; II) ligar el surgimiento del peronismo -el "17 de Octubre" - con la gesta revolucionaria de Mayo; y III) enlazar la forma de irrupción -la movilización de octubre del 45- con el contenido del peronismo -las políticas públicas que llevó adelante en el gobierno-. Son estos puntos los que permiten poner en cuestión la supuesta reticencia de ciertos grupos peronistas de los años sesenta para recuperar la experiencia del periodo "1945-1955" y, también, la que sostiene que, para aquellos años, todo el peronismo se pensaba revolucionario. En Compañero, en este sentido, hay una recuperación de la “década peronista” que no está exenta de tensiones, ya que se marca, por ejemplo, en los propios orígenes del peronismo el nacimiento de una corriente conciliadora y burocrática. Aun así, puede contraponerse el delineamiento que hace el semanario respecto de una esencia revolucionaria peronista que habría sido obturada a las afirmaciones que marcan una inexistencia de una recuperación del periodo 45-55 en el "peronismo revolucionario" de los primeros años sesenta.

Asimismo, la erección de una "naturaleza" revolucionaria involucraba una cuestión capital para el semanario. La situación de penuria y desasosiego que vivió el peronismo con posterioridad al golpe de 1955 tenía también una dimensión positiva: ella demostró un presunto alto grado de politización y combatividad en las huestes peronistas. Precisamente, esto era lo que los "esténtores revolucionarios" de junio de 1956, enero de 1959 y marzo de 1962 mostrarían: la combatividad y el espíritu de lucha, ahogados por el accionar de los “elementos burocráticos". En este sentido, la constitución del MRP en agosto de 1964, un nuevo mojón 
pero aun así relacionado con los anteriores, debía constituirse en la plataforma a partir de la cual renovar las dirigencias políticas y sindicales con aquellos "leales" a Perón. Sólo así, al parecer, ese río caudaloso que eran las masas podría ser reconducido.

No obstante estos resultados, posteriores análisis deberán hacer comparecer las diversas construcciones del fenómeno peronista en "clave revolucionaria" en otras manifestaciones del peronismo de los años sesenta y analizar si las inclinaciones que se vislumbran en Compañero son cimentaciones originales o si, como es lógico pensar, son producto del zeitgeist de una época. Es el caso, como se dijo, de las distintas significaciones que asumió la "revolución" para el peronismo de estos años. El semanario Compañero, en este sentido, es una de las puertas de entrada posibles para examinar las reapropiaciones que se produjeron respecto de la tradición peronista en la década del sesenta. Estodebe llevar, asimismo, a ir un paso más allá de algunas conclusiones o intuiciones "clásicas" sobre el derrotero del movimiento liderado por Perón en el periodo que se abre tras la asonada militar de septiembre de 1955. En definitiva, no presentar a las manifestaciones peronistas de principios de 1960 -el caso de Compañero-como experiencias in nuce de las organizaciones político-militares peronistas de los setenta -como parecen sugerir Daniel James, Richard Gilliespie o Lucas Lanusse-. De lo que se trata, más bien, es de reponer las expresiones particulares de aquellos grupos que desarrollaron su labor política en un periodo de intensos y rápidos cambios. El semanario Compañero, en este sentido, es tan sólo una muestra de las tensiones a las que se vio sometida la tradición peronista en estos años. Aquí, finalmente, la teoría de las identidades políticas tiene un arduo trabajo: desmalezar un terreno con el auxilio tanto de la teoría como de la historia, sin apelar a explicaciones omniabarcativas al solo efecto de simplificar complejos procesos sociopolíticos. Es una labor espinosa si no se acepta que identidad e historia, cual cinta de Möbius, no son términos opuestos y separados sino más bien son continuos y se corresponden mutuamente.

\section{ReFERENCIAS}

Aboy Carlés, G. (2001). Las dos fronteras de la democracia argentina. La redefinición de las identidades politicas de Alfonsin a Menem. Rosario: Homo Sapiens.

Altamirano, C. [2001] (2013). Peronismo y cultura de izquierdas. Buenos Aires: Siglo XXI.

Arendt, H. [1972] (2015). Crisis de la república. Buenos Aires: Cuenco de Plata.

Arendt, H. [1963] (2012). Sobre la revolución. Madrid: Alianza.

Arendt, H. [1954] (2016). Entre el pasado y el futuro. Buenos Aires: Ariel.

Anzorena, O. (1989). Historia de la Juventud Peronista (1955-1988). Buenos Aires: Del Cordón.

Balbi, F. A. (2007). De leales, desleales y traidores. Valor moral y concepción de politica en el peronismo. Buenos Aires: Antropofagia.

Baschettii, R. (2012). Documentos de la Resistencia Peronista. 1955-1970. Vol. I. Buenos Aires: Campana de Palo.

Bozza, J. (2001). El peronismo revolucionario. Itinerario y vertientes de su radicalización. 1959-1969. Sociohistórica, 9-10, 135-169.

Cooke, J. W. (2014). Correspondencia Perón-Cooke. Buenos Aires: Colihue.

Damin, N. (2010). Plan CONINTES y Resistencia Peronista. 1955-1973. Buenos Aires: Instituto Nacional Juan Domingo Perón de Estudios e Investigaciones Históricas, Sociales y Política.

Ehrlich, L. (2012). Intransigentes, duros y revolucionarios. Variaciones en la cultura politica peronista entre 1955 y 1963 (Tesis doctoral inédita). Facultad de Filosofía y Letras, Universidad de Buenos Aires, Buenos Aires.

Georgieff, G. (2008). Nación y revolución. Itinerarios de una controversia en Argentina (1960-1970). Buenos Aires: Prometeo.

Gil, G. (1989). La izquierda peronista. Buenos Aires: CEAL.

Gillespie, R. (1982). Soldados de Perón. Buenos Aires: Sudamericana. 
Giménez, S. (2014). Un partido en crisis, una identidad en disputa. El radicalismo en la tormenta argentina (1930-1945) (Tesis doctoral inédita). Facultad de Ciencias Sociales, Universidad de Buenos Aires, Buenos Aires.

Gramcsi, A. [1948] (2003). El materialismo histórico y la filosofía de Bendetto Croce. Buenos Aires: Nueva Visión.

Hobsbawn, E. (1983). Introduction: Inventing Traditions. En E. Hobsbawm y T. Ranger,The Invention of Traditions (pp. 1-14). Cambridge: Cambridge University Press.

James, D. (1995). El 17 y 18 de Octubre de 1945: El peronismo, la protesta de masas y la clase obrera argentina. En J. C. Torre (Comp.) El 17 de octubre de 1945 (pp. 83-129). Buenos Aires: Ariel.

James, D. (1990). Resistencia e integración. Buenos Aires: Sudamericana.

James, D. (1976). The Peronist Left. 1955-1975. Journal of Latin American Studies, 8(2), 273-296.

Laclau, E. (1996) Emancipación y diferencia. Buenos Aires: Nuevo Visión.

Lanusse, L. (2005). Montoneros. El mito de sus 12 fundadores. Buenos Aires: Vergara.

Lobato, M. Z. y Tornay, L. (2005). La política como espectáculo: imágenes del 17 de octubre. En S. Sené González y G. Lerman (Comp.) El 17 de octubre de 1945. Antes, durante y después (pp. 221-240). Buenos Aires: ed. Lumiere.

Luna, F. (1985). Perón y su tiempo. II La comunidad organizada 1950-1952. Buenos Aires: Sudamericana.

McGuire, J. [1993] (2004). Perón y los sindicatos: la lucha por el liderazgo peronista. En S.Amaral y M. B. Plotkin (Comp.) Perón: del exilio al poder (pp. 161-203).Saénz Peña: EDUNTREF.

Melo, J. (2009). Fronteras populistas. Populismo, peronismo y federalismo entre 1943 y 1955 (Tesis doctoral inédita). Facultad de Ciencias Sociales, Universidad de Buenos Aires, Buenos Aires.

Melón Pirro, J. C. (2014). Normalización partidaria en tiempos de proscripción. El peronismo entre 1963 y 1965 . En J. C. Melón Pirro y N. Quiroga (Comp.) El peronismo y sus partidos. Tradiciones y prácticas politicas. 1946-1976 (pp. 149-167). Rosario: Prohistoria.

Melón Pirro, J. C. (2011). Un partido en situación de espera. Los alineamientos políticos del peronismo en el segundo momento de la proscripción, 1963-1964. En J. C. Melón Pirro y L. Da Orden (Comp.) Organización política y Estado en tiempo del peronismo (pp. 61-73).Rosario: Prohistoria.

Navarro, M. (1995). Evita y la crisis del 17 de octubre de 1945: un ejemplo dela mitología peronista y antiperonista. En J. C. Torre (Comp.) El 17 de octubre de 1945 (pp. 149-170). Buenos Aires: Ariel.

Neiburg, F. (1995). El 17 de Octubre de 1945. Un análisis del mito de origen del peronismo. En J. C. Torre (Comp.) El 17 de octubre de 1945 (pp. 219-283). Buenos Aires: Ariel.

Raimundo, M. (2001). Compañero y los orígenes del Peronismo Revolucionario. Sociohistórica, 8, 203-226.

Raimundo, M. (1998). La política armada en el peronismo: 1955-1966. Cuadernos del CISH, 3(4), 201-231.

Rancière, J. [1996] (2007). El desacuerdo. Política y filosofia. Buenos Aires: Nueva Visión.

Renan, E. [1882] (2010). ¿Qué es una nación? Buenos Aires: Hydra.

Restrepo, E. (2007). Identidades: planteamientos teóricos y sugerencias metodológicas para su estudio. Revista Jangwa Pana, 5, 24-35.

Perón, J. D. [1958] (1974). Los vendepatria. Buenos Aires: Liberación.

Perón, E. [1952] (2006). La razón de mi vida. Buenos Aires: CS Ediciones.

Perón, E. [1951] (1987). Historia del peronismo. Buenos Aires: Volver.

Plotkin, M. B. (1995). Rituales políticos, imágenes y carisma: La celebración del 17 de octubre y el imaginario peronista 1945-1951. En J. C. Torre (Comp.), El 17 de octubre de 1945 (pp. 171-217). Buenos Aires: Ariel.

Quattrochi-Woisson, D. (1995). Los males de la memoria. Historia y politica en la Argentina. Buenos Aires: Emecé.

Sarlo, B. (2003). La pasión y la excepción. Buenos Aires: Siglo XXI.

Sarlo, B. (1999). Eva Perón: algunos temas. En C. Altamirano (Comp.) La Argentina en el siglo XX (pp. 341-351). Buenos Aires: Ariel.

Slipak, D. (2015). Las revistas montoneras. Buenos Aires: Siglo XXI. 
Slipak, D. (2013). De lealtades y tradiciones. El enfrentamiento de la JP Lealtad con Montoneros a través de sus revistas. Estudios Sociológicos, 31(92), 345-367.

Spinelli, M. E. (2005). Los vencedores vencidos. Buenos Aires: Biblos.

Tcach, C. [2003] (2014). Obreros rebeldes, sexo y religión en el origen del peronismo cordobés. En D. Macor y C. Tcach. (Comp.), La invención del peronismo en el interior del pais (pp. 33-55). Santa Fe: UNL Ediciones.

Tcach, C. [2003] (2007). Golpes, proscripciones y partidos políticos. En D. James (Dir.), Nueva Historia Argentina. Violencia, proscripción y autoritarismo: 1955-1976. Tomo IX (pp. 17-62). Buenos Aires: Sudamericana.

Torre, J. C. [1990] (2011). La vieja guardia sindical y Perón. Buenos Aires: Sudamericana.

Verón, E. y Sigal, S. [1986] (2014). Perón o muerte. Los fundamentos discursivos del fenómeno peronista. Buenos Aires: Eudeba.

Weber, M. [1967] (2007). Elpolitico y el cientifico. Madrid: Alianza.

Yannuzzi, M. A. (2002). Homogeneidad e heterogeneidad: la ambivalencia de la identidad. En C. Battcok, B. Dávilo, M. Germain, C.Gotta, A. Manavella y M. L. Múgica (Coords.) Espacio, memoria e identidad (pp. 282-288). Rosario: UNR Editora.

Zizek, S. [1989] (2009). El sublime objeto de la ideología. Buenos Aires: Siglo XXI.

\section{Fuentes}

Compañero, 79 números, junio de 1963 a abril de 1965.

Cuadernos de Compañero, número 3, noviembre 1964.

\section{ENTREVISTA}

Conversación con Facundo Carman, 6 de abril de 2017.

\section{Notas}

1 Este fue el nombre que diarios como La Nación y La Prensa dieron a algunas acciones de Perón y su movimiento después de la frustrada elección del 18 de marzo de 1962 y el posterior desplazamiento de Arturo Frondizi tan sólo once días después. La categoría fue utilizada no sólo por los propios peronistas -son los casos, por ejemplo, del dirigente textil Andrés Framini y del antiguo delegado personal de Perón, John William Cooke-. El Secretario General del Partido Comunista, Victorio Codovilla, por ejemplo, publicó aquel mismo año El significado del giro a la izquierda del peronismo, en el cual trató de desentrañar qué significaba el presunto cambio en la matriz ideológica del peronismo y cómo deberían posicionarse frente a ello los comunistas. Aún sin competer específicamente a este artículo, la categoría es útil para desentrañar algunos sutiles pero persistentes cambios que comenzaron a operar dentro del movimiento liderado por Perón. Para ampliar en las repercusiones que tuvo el "giro a la izquierda" para los sectores combativos o intransigentes del peronismo en aquellos momentos posteriores al 29 de marzo de 1962, se sugiere Laura Ehrlich (2012).

2 El rol de Villalón no fue celebrado por todos. John William Cooke, en su carta a Perón del 12 de septiembre de 1964, se refería a este como un "revolucionario de carnaval" (2014, p. 589). Un militante de la Juventud Peronista de los primeros años sesenta como Jorge Rulli aduce que Villalón no era más que un personaje que utilizaba Perón para conseguir fondos económicos vía Cuba, cuyas promesas de que "cada joven peronista tiene que tener su fusil" se desvanecían en el aire (Anzorena, 1989, p. 81).

3 Asimismo, junto a estos números, se editaron en julio y septiembre de 1963, y noviembre de 1964 los Cuadernos de Compañero. Estas entregas se orientaban a tratar temáticas particulares. Por ejemplo, se analizaba el "Discurso de Punta Lara” de Andrés Framini (primer número), la restructuración del peronismo en el marco de las elecciones de julio de 1963 (segundo número) y el trazado de una historia del peronismo desde el 17 de octubre de 1945 a la constitución del Movimiento Revolucionario Peronista (MRP) en agosto de 1964 (tercer y último número).

4 Esto fue señalado por Facundo Carman en una entrevista con el autor. 14 de mayo de 2017.

5 Como sucede también con otros términos - por ejemplo pueblo, democracia, Nación, entre otros- el de revolución es un significante que es disputado por formaciones discursivas diversas. Es decir, opera como aquello que Ernesto Laclau 
(1996) denominó significante vacio: términos que, vaciándose tendencialmente de su significado particular, pueden ser articulados -y por ello resignificados- en proyectos hegemónicos diversos e incluso opuestos. Así, por ejemplo, el significante revolución no sólo aparece simultáneamente en Compañero y en el Boletín Informativo Semanal de las Actividades de la Confederación General del Trabajo -órgano oficial de la CGT y por ello objeto de polémicas con el semanario-, sino que también ambas publicaciones significan la "revolución" de distintos modos. En este sentido, queda pendiente para futuros trabajos examinar los puntos de divergencia y de confluencia que ambas significaciones de la "revolución" o de lo "revolucionario" han presentado en las fuentes antes mencionadas.

6 Desde el golpe de Estado de septiembre de 1955, la "Revolución Libertadora” había prohibido cualquier tipo de manifestación pública y organizada en recuerdo de aquella fecha. A partir de allí, su conmemoración adquirió otro sentido; "se convirtió en una fecha en la que se exteriorizaba la protesta: pintadas en las paredes, el estallido de un petardo, anuncio de paros generales y planes de luchas” (Lobato y Tornay, 2005, p. 236). Asimismo, y como marca Ehrlich (2012, p. 154), las provincias del interior se convertirán, frente a la prohibición que pesaba sobre Buenos Aires, en los escenarios predilectos para los actos y manifestaciones en recuerdo al “17 de Octubre”. Son los casos de Tucumán, Córdoba y Santa Fe, por ejemplo.

7 En discusión con este autor, Ehrich señala que los principales temas que estructuraron a los “duros” venían impregnados por la "retórica y el repertorio de temas de los sectores políticos (no sindicales) de la intransigencia peronista (...) forjados en la oposición al gobierno de la 'Revolución Libertadora' y circularon en las publicaciones periódicas peronistas” reformulándose a través de éstos la combatividad del peronismo en la proscripción (2012, p. 196). Aunado a la crítica de la historiadora, es posible decir que allí donde James ve un "estado de ánimo" o una "estructura de sentimientos" supuestamente no político, se está ante una categoría eminentemente política; esto es, una categoría que produce un agrupamiento entre "amigos" y "enemigos", para decirlo en términos schmittianos.

8 Fernando Balbi (2007, pp. 27 y 28) ha llamado la atención sobreque para el Perón de Conducción política [1951], el Movimiento no era otra cosa que la reunión bajo la conducción centralizada del propio Perón de fuerzas y sectores heterogéneos que no podían o querían confluir en una misma organización. Era la Doctrina Nacional (peronista) la que daba unidad a esas fuerzas heteróclitas.

9 Respecto a esta puesta en cuestión, se señala en el semanario: "Cuando el 17 de octubre las clases trabajadoras argentinas se movilizan e imponen - por primera vez en nuestra historia- su voluntad de participar en los destinos de la Nación, muchas cosas cambian en la Argentina, muchos valores establecidos hasta ese momento inamovibles e intocables se trastocan y perimen (...) Esas masas que en el atardecer de la memorable jornada aclaman al líder rescatado acaban de pisotear muchos tabús, acaban de abrir una brecha profunda e indeleble en el cuerpo de la Argentina 'tradicional'" (Compañero, No 52, 1964, p. 4). Para ahondar en este trastrocamiento de los valores tradicionales producto del acaecer mismo del "17 de Octubre", se recomienda Daniel James (1995, pp. 83-129).

10 Aserciones de este tipo son contrarias al pensamiento, por ejemplo, de autores como Gil (1989, p. 46) y Diana Quattrochi-Woisson (1995, p. 321). Aún a pesar de las diferencias que se vislumbran entre ambos, existe un punto en el que parecen coincidir: la política parece servirse de la historia, lo que ocasiona que esta última sea distorsionada. Esto es, se enturbia el verdadero significado de la historia. En este sentido, actividad política y trabajo historiográfico deberían ir por caminos separados. Ahora bien, ¿es posible que la política no apele a la historia para dotarse de legitimidad? ¿Es factible la labor del historiador allende la política? Como ya se anticipó, política e historia, historia y política, parecen corresponderse mutuamente.

11 Algo similar había notado ya antes Aboy Carlés (2001, p. 126).

12 Asegura Raimundo: "Al proponer [Compañero] políticas que formulaban 'barrer con la dirección burocratizada y entregada al enemigo' provocaron una tensión con la tradicional prédica de 'unidad del movimiento', aunque si bien todavía -en relación a estos sectores radicalizados-, estamos en un estadio en el que se considera que todo el peronismo es revolucionario" (2001, p. 217). Sosteniendo finalmente en una nota al pie: "más adelante habrá un peronismo revolucionario y otro no".

13 En su clásico Peronismo y cultura de izquierda [2001] (2013), Carlos Altamirano aduce que luego de 1955 el peronismo parece adquirir una doble existencia entre un peronismo verdadero y otro empírico. Mientras el primero se refiere a un peronismo inactual pero pleno en el pasado -coincidente con la "década peronista"-, mayoritario pero excluido y reacio al encorsetamiento doctrinario, el peronismo empírico, su contracara exacta, configuraría lo no-verdadero y lo minoritario.

14 Valdría la pena reparar en el modo en que se configuran las dos columnas en la nota. De un lado, a la izquierda, están las imágenes de Eva Perón - "Vigía de la Revolución y abanderada del Pueblo"-, de un grupo de jóvenes -"Las masas en la calle son la garantía del triunfo sobre la reacción”-, de Felipe Vallese - "Vallese, Medina, Bevilacqua, Mendoza. Mártires del Pueblo y acusación permanente contra la burocracia"- de un grupo de personas armadas - "La clase trabajadora lucha contra la opresión y la miseria con todos los medios"- y la de la asamblea que constituye el MRP - "El 5 de agosto, el peronismo revolucionario aprueba los históricos documentos y declara su vocero a Compañero"-. Del otro, a la derecha, están las imágenes de Pedro Eugenio Aramburu - "El símbolo máximo de infamia y la traición de la democracia”-, la 
Oscar Albrieu -“Abrieu usufructúa posiciones otorgadas graciosamente por los asesinos del pueblo”-, la de Augusto Vandor y Alberto Iturbe - "[N]uevos mentores de la conciliación con las fuerzas de ocupación”-, la de Miguel Gazzera y Vicente Solano Lima - “[L]os tránsfugas le abren la puerta a la oligarquía a través del frentismo”- y la de José Alonso y Antonio Caggiano - “[I]magen de la actitud capituladora de la burocracia que 'liquidó' el Plan de Lucha”-.

15 Esta versión está presente en la lectura que hace Eva Perón en la Escuela Superior Peronista en 1951 y luego publicado en Historia del peronismo [1952] (Navarro, 1995, p. 168). En su trabajoLa vieja guardia sindical y Perón [1990] (2011), Juan Carlos Torre desanda la versión de que la movilización se produjo al margen de las organizaciones sindicales. La sincronización de la movilización obrera es el índice a partir del cual el autor cuestiona tal arraigada versión.

16 Casi treinta años más tarde, la "teoría del cerco" será también una temática cara y urticante para Montoneros. Como muy bien marcan Verón y Sigal ([1986] 2014, pp. 179-194), mediante la imagen del cerco se imaginaba que entre la Juventud Peronista y Perón se encontraban empotrados intermediarios “burocráticos” que distorsionaban la comunicación clara y frontal entre ambos. Era la intermediación de esos intereses los que explicaban las decisiones y acciones del líder, muchas veces contrarias a los intereses de los sectores juveniles del peronismo. Este comodín explicativo, no obstante, sufrió algunas modificaciones a partir del tercer gobierno peronista, esbozándose algunas críticas a Perón sin por ello redimir a los sectores sindicales (Slipak, 2013, p. 360).

17 En vísperas a las elecciones de noviembre de 1951, el 22 de agosto se llevó a cabo el Cabildo Abierto del Justicialismo en el Ministerio de Obras Públicas donde se lanzaría la fórmula presidencial "Perón-Perón". Luego de dos horas de deliberación pedidas a su anonadado auditorio, Evita renunció a la candidatura a vicepresidente. Para Félix Luna (1985, pp. 188-191), la declinación de Evita formó parte de una estrategia diseñada por Perón para rehuir de las rencillas internas que se hubiesen formado para cubrir el puesto de vicepresidente de cara a las elecciones de noviembre.

18 Esta idea es disímil a la hallada por Daniela Slipak (2015, pp. 83-92) para el caso de El Descamisado. Empero, mientras en Compañero se aduce que el pueblo presentó en el decenio peronista un alto grado de politización y combatividad, para la publicación ligada a la organización político-militar Montoneros, fue el acaecer de la "Revolución Libertadora" el que despertó esa combatividad en el pueblo.

19 CONINTES fue el nombre que recibieron una serie de disposiciones del Poder Ejecutivo durante el gobierno de Arturo Frondizi (1958-1962), las cuales dotaron a las Fuerzas Armadas del poder para intervenir, vía represión, en los conflictos políticos internos. Para ampliar sobre la repercusión del CONINTES en la militancia peronista, ver Nicolás Damin (2010).

20 Algo similar concluía la Fuerza de Orientación Radical de la Joven Argentina (FORJA) a fines de los años treinta. Como muestra Sebastián Giménez, la novedad principal que supuso FORJA para el radicalismo de los 30 fue el hecho de construir un "espacio para que la UCR se concibiera a distancia del dispositivo electoral" (2014 p. 172). Esto explica que para el forjista Arturo Jauretche, como anota Giménez, de lo que se trataba era de retrotraer la fuerza radical a los orígenes situados antes de la sanción de la Ley Sáenz Peña en 1912 (2014, p. 171).

21 El “Consejo... "apareció en octubre de 1958. Constituyó la segunda institución creada por Perón para suplir la carencia de una organización partidaria propia y disuadir liderazgos locales. "Según instruyó su creador, la función del organismo sería de la 'colaborar' en la dirección táctica, y debía dedicarse exclusivamente a organizar las fuerzas políticas dejando la de las sindicales a las 62 y la CGT, sin ninguna intervención del CCS. Fue la voz oficial del peronismo a la hora de propiciar el voto en blanco en 1960 luego de prohijar un congreso justicialista frustrado por una nueva proscripción y jugó un papel de articulador de la concurrencia electoral en 1962 mediante el apoyo a siglas como la Unión Popular” (Melón Pirro, 2014, pp. 151 y 152). 